\title{
Asymmetric and Symmetric Link between Quality of Institutions and Sectorial Foreign Direct Investment Inflow in India: A Fresh Insight Using Simulated Dynamic ARDL Approach
}

\author{
Faheem Ur Rehman ${ }^{1,2}$, József Popp ${ }^{3,4, * \mathbb{C}}$, Ejaz Ahmad ${ }^{5}$, Muhammad Asif Khan ${ }^{6,7, *}$ and Zoltán Lakner 8 \\ 1 Graduate School of Economics and Management, Ural Federal University, Mira 19, \\ 620002 Ekaterinburg, Russia; rehman@urfu.ru \\ 2 Department of Economics, The University of Haripur, Haripur 22620, Pakistan \\ 3 Hungarian National Bank-Research Center, John von Neumann University, 6000 Kecskemét, Hungary \\ 4 Department of Public Management and Governance, College of Business and Economics, University of \\ Johannesburg, Johannesburg 2006, South Africa \\ 5 Department of Economics, Kohat University of Science and Technology, Kohat 26064, Pakistan; \\ ahmad@uoh.edu.pk \\ 6 Department of Commerce, Faculty of Management Sciences, University of Kotli, Kotli 11100, Pakistan \\ 7 Department of Business Management, College of Business and Economics, University of Johannesburg, \\ Johannesburg 2092, South Africa \\ 8 Department of Food Chain Management, Institute of Agribusiness, Hungarian University of Agriculture and \\ Life Sciences, 2100 Gödöllő, Hungary; Lakner.Zoltan.Karoly@uni-mate.hu \\ * Correspondence: popp.jozsef@uni-neumann.hu (J.P.); adatalib@hotmail.com (M.A.K.)
}

Citation: Rehman, F.U.; Popp, J.; Ahmad, E.; Khan, M.A.; Lakner, Z. Asymmetric and Symmetric Link between Quality of Institutions and Sectorial Foreign Direct Investment Inflow in India: A Fresh Insight Using Simulated Dynamic ARDL Approach. Sustainability 2021, 13, 13760. https:// doi.org/10.3390/su132413760

Academic Editors: Marek Durica,

Lucia Svabova, Jaroslav Frnda and Katarina Kramarova

Received: 6 November 2021

Accepted: 6 December 2021

Published: 13 December 2021

Publisher's Note: MDPI stays neutral with regard to jurisdictional claims in published maps and institutional affiliations.

Copyright: () 2021 by the authors. Licensee MDPI, Basel, Switzerland. This article is an open access article distributed under the terms and conditions of the Creative Commons Attribution (CC BY) license (https:// creativecommons.org/licenses/by/ $4.0 /)$.

\begin{abstract}
This study explores the bicausality between institutional quality and FDI inflow both aggregated and sector-wise, i.e., the agricultural, manufacturing, and tertiary sectors in the Indian economy, by applying simulated autoregressive distributed lag (SARDL) dynamic new techniques, an extended variant of orthodox ARDL and NARDL. The study confirms that aggregated and sectorial FDI are enhanced by adequate institutional quality, and similarly, FDI promotes quality institutions. The nexus between institutional quality and FDI inflow is an inspiration for India to compete with developed economies by enhancing its institutional quality. The study observes cointegration and bidirectional causality between institutional quality and aggregated FDI.
\end{abstract}

Keywords: sectorial FDI inflow; institutional quality; simulated ARDL dynamic; India

\section{Introduction}

Foreign direct investment (FDI) bridges the gap between savings and investment requirements [1]. Endogenous growth theories emphasize that FDI is a crucial predictor of economic growth since it is a source of technical transfer from industrialized countries to developing countries as a result of globalization. By strengthening the skills and knowledge of workers in the host country, FDI can reduce unemployment both directly and indirectly. Many developing countries have implemented policies to ease FDI inflows and regulate FDI operations. Financial sector adjustment, structural adjustment, economic recovery, and economic partnership agreements are examples of these types of programs [2]. FDI has been increased in emerging economies since 1990, including the Association of Southeast Asian Nations (ASEAN), Sub-Saharan African countries, South Asian Association of Regional Cooperation (SAARC) members, and Central Asian economies. FDI inflows support these developing countries by improving technology, managerial skills, and increasing exports, employment, productivity, economic growth, and capital accumulation.

In the last decade, the impact of institutional quality on FDI has gained special interest in research. There exists a lot of literature in support of the idea that quality institutions enhance FDI and cause capital mobility in the international market $[3,4]$. However, very limited literature exists on FDI's role in institutional quality promotion in host countries. 
Good quality institutions significantly enhance FDI inflow [5,6], while poor institutional arrangements such as the law and order situation, investor protectionism, political stability, government policies, and formal and informal codes of conduct have a negative impact on investment inflow.

We highlight several ways through which institutional quality attracts FDI inflow, and reversely, FDI promotes institutional quality in a host economy. Foreign investors are interested in institutional quality because it deceases the business implementation and operational costs in host countries. Meanwhile, poor institutions discourage FDI inflow, such as taxes, thus increasing the FDI opportunity cost $[7,8]$. Investors hesitate and are discouraged from investing in countries where red tape, nepotism, and corruption are encouraged by institutions because these are the determinants of business operational costs $[9,10]$. The author of [11] suggested that a lack of good governance in institutions is substituted with taxation and discourages foreign investors. In [12], it was reported that in developing countries' red tape, substandard legal systems, and corruption significantly deter FDI inflow. The positive role of FDI in economics has turned a self-evident truth where technological, savings, and investment gaps are covered by foreign firms through the provision of technology and cash to the recipient economy. FDI provides an opportunity to local firms for learning from foreign firms either by collaborating with these firms or watching and infusing a sense of competition among local firms and institutions in order to boost the host country's productivity. In [13], it was suggested that competition in attracting FDI has a positive contribution in FDI-aspirant countries, calls for prodigious positive change from FDI, and introduces to rival recipient countries a race to the top. FDI not only transfers innovation in productive technology, but it also improves the institutional qualities that contribute to the domestic economy. Many studies have found a corruptive relationship with economic openness [14-16], but very limited studies have highlighted the impact of FDI on institutional quality.

The author of [17] explored how FDI impacts institutional quality through the channeling of the market forces of demand and supply. In [18], it was pointed out that FDI has reduced corruption levels in recipient countries and has justified that this is due to good governance and better management practices from foreign investors. In [19], it was suggested that FDI induced technological innovation and institutional efficiency, which are very determinant of economic growth. Although FDI and institutional quality are very important for economic growth, there is very limited literature on the causal relationship between FDI and institutional quality. The existing literature does not clarify the relationship between FDI and institutional quality. First of all, these studies have explained the FDI and institutional quality relationship by employing aggregated data of FDI, which provide a blurred picture of FDI's causal relationship with institutional quality. Secondly, these studies focused only on one aspect of institution quality, i.e., political risk and corruption, to explain the impact of institutional quality and FDI. Thirdly, these studies are based on cross-country analyses that lead to ambiguous results due to the existence of heterogeneity issues [20].

On these grounds, this study employs a set of indicators for evaluating the overall impact of institutional quality on sectorial FDI and, reversely, how sectorial FDI effects the quality of institutions in India with a focus on single-country analysis for the formulation of policies based on strong foundations. We have not found any empirical study on the bidirectional causality of institutional quality and sectorial FDI inflow of any sector, i.e., agriculture, industrial, and service sectors. Simulated ARDL techniques are applied in this study for the investigation of the short-run and long-run bidirectional causality of institutional quality and sector-wise FDI inflow (primary, secondary, services) in India. The simulated ARDL dynamic model overcomes the problems faced in orthodox ARDL in the exploration of short-run and long-run diverse model specifications. In [21], a novel dynamic simulated ARDL technique was devised, which we used in the current study. This innovative model can automatically stimulate, estimate, and plot graphs of positive and negative fluctuations in variables, as well as their short and long-term correlations. 
The ARDL model in [22], on the other hand, can only estimate the long- and short-run associations between the variables.

The study is organized as follows: Institutional quality and FDI trends in India are explained in Section 2. Section 3 shows the Literature Review. This is followed by detailed methodology, data source, and econometric models. Next, the study's empirical results are evaluated and, finally, conclusions are presented, and some policy recommendations are suggested.

\section{FDI Trends and Institutional Quality in India}

This section deals with trends and the structural pattern of FDI inflows in India. The FDI inflow distribution in India has two dimensions: first, government-prevailed treatments of FDI inflow in specified sectors, and secondly, it shows preferential investment of multinational cooperation among different sectors. India, the world's second most populous country, has great potential growth and is very suitable for FDI (see Figure 1). The institutional quality of India is good in Asian economies, which is the reason why it has achieved remarkable achievement in FDI attraction from the FY-2008 and onward $[18,23,24]$. FDI inflow in India has increased by 55\% from USD 231.37 billion to USD 358.29 from the period 2008-2014 to 2014 to 2019 [23]. However, it still needs improvement as it is below other emerging economies such as China and Singapore, etc.

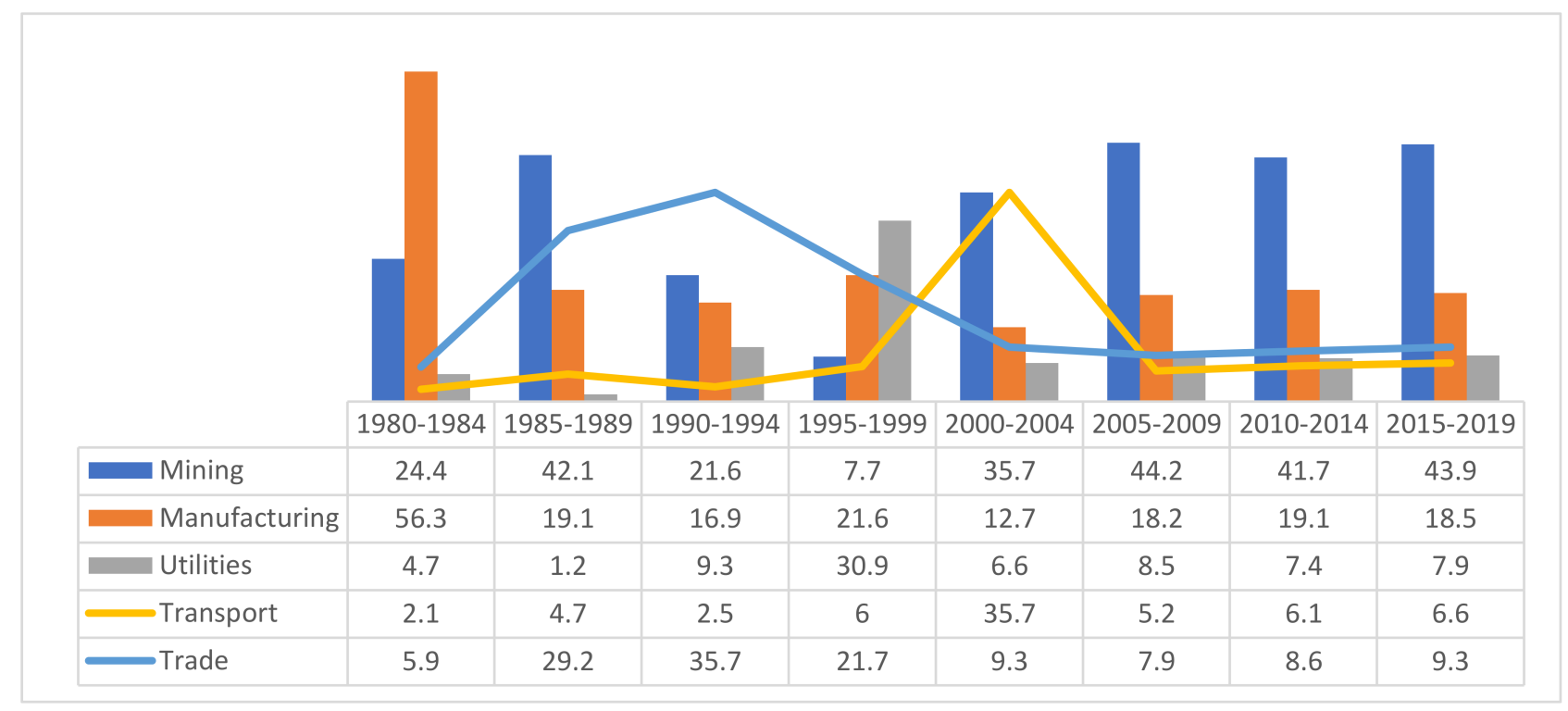

Note: Mining: quarrying, oil, and gas mining; Manufacturing: manufacturing; Utilities: power and utilities; Trade: Commerce and trade; Transport: transport, communications, storage, social, personal, and financial services.

Figure 1. Percentage of various economic groups in total FDI. Source: Authors own calculations.

Figure 1 indicates that Indian FDI has significantly changed from one sector to another in last 30 years. In the 1980s, foreign investors were interested in investing in the manufacturing, quarrying, and mining sectors, and these sectors' shares were greater than $80 \%$ from 1980 to 1984 . The shares of these sector were dropped to 30\% from 1995 to 1999 and then raised to $40 \%$ in 2000 to 2004 (see Figure 2). The radical decline in manufacturing sector FDI was initially replaced by the commerce, mining, and quarrying sectors and after that replaced by the personal services, social services, financial, communication, and transportation sectors. This proved that sectorial preferences continuously changed in Indian FDI in the last 30 years. In the same way, the pre- and post-reform distribution of sector-wise FDI (primary, secondary, and services) shows a significant variation. In the pre-reform period, the manufacturing, mining, and quarrying sectors' shares drastically decreased, and the services sector's shares increased. FDI shares in the services sector has 
increased from $2.2 \%$ to $45 \%$ from the period $1980-1994$ to 1995 to 2010 . The performance analysis of FDI in the pre- and post-reform index is calculated and shows relative sectorial FDI contribution in total GDP, as mentioned in Figure 2. A sector with value greater than one means that it has gained more FDI as compared to the relative economic size of that sector. We calculate as follows:

$$
S F P I=\frac{F D I_{i} / F D I_{t}}{G D P_{i} / G D P_{t}}
$$

where $\mathrm{FDI}_{\mathrm{i}}$ represents i sector FDI, $\mathrm{FDI}_{t}$ means total FDI, GDP $\mathrm{I}$ means i sector GDP, and $\mathrm{GDP}_{\mathrm{t}}$ means total GDP.

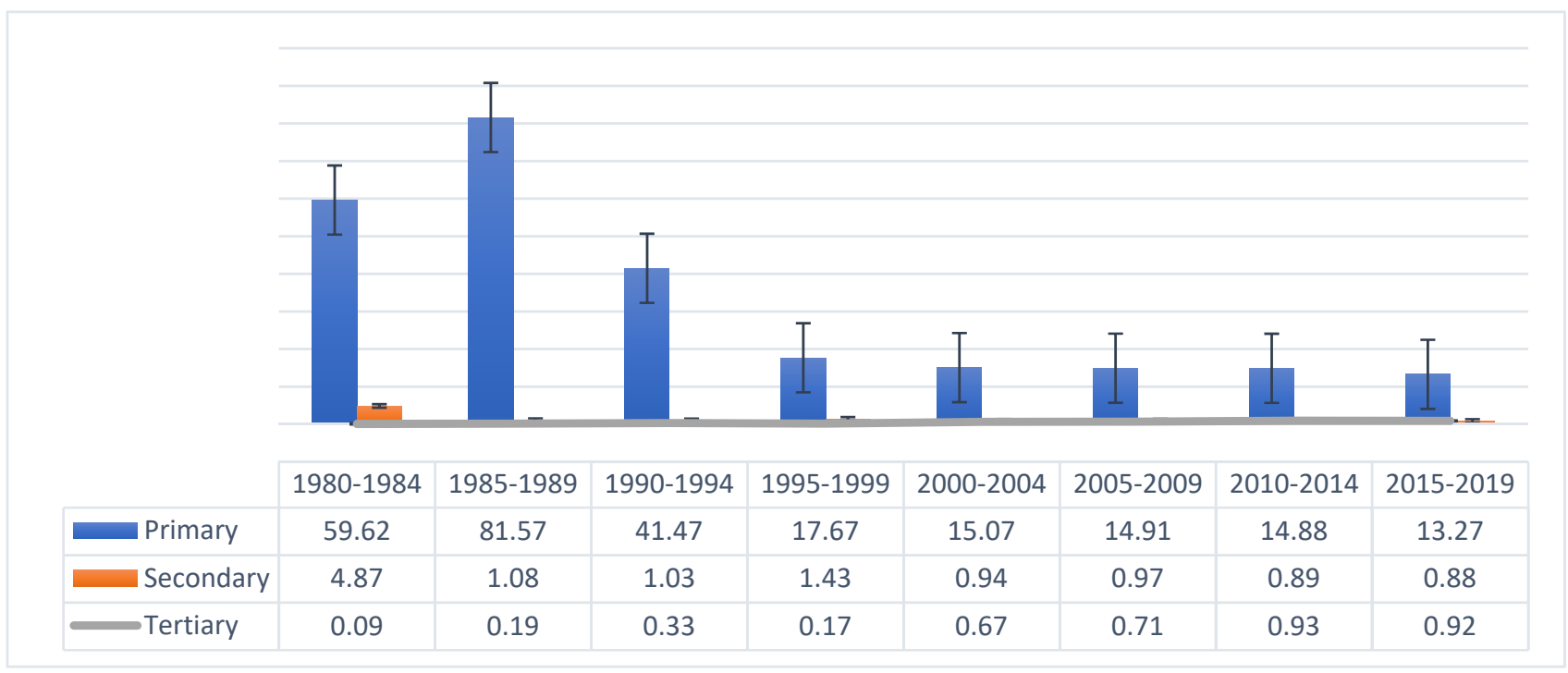

Figure 2. Sector-wise performance index of FDI. Source: Authors own calculations.

Figure 2 shows a significant variation in sectorial FDI in the pre- and post-reform periods. The sectorial performance index indicates that mining, oil, and gas (primary sector) FDI inflows have huge shares in the GDP in the pre-reform period. The manufacturing sector FDI is comparatively low in the post-reform period, and the services sector's FDI share has increased in the total GDP. If we consider Indian institutions as social structure governance behavior of individuals, then Indian institutional quality may not be encouraging as India has experienced corruption, lack of governance, worse law and order, and political instability. Table 1 and Figure 3 shows that the average Indian institutional quality index is 5.3, with a maximum institutional quality index of 12 . Similarly, India ranked low in all six selected components of institutional quality. The Standard Deviation (SD) of all these components shows that bureaucratic quality is comparatively more stable. Overall, the Indian institutional quality index is low as compared to other emerging economies (See Figure 3 and Table 1).

Table 1. Indian Quality of Institution Index (1980-2019).

\begin{tabular}{cccccc}
\hline & IIQ & WR & Min Value & Max Value & SD \\
\hline Invest.Profile & 6.31 & 113 & 3.11 & 7.93 & 1.42 \\
Law and orders & 6.17 & 104 & 2.5 & 7.31 & 0.67 \\
Political & 8.16 & 97 & 2.47 & 10.37 & 2.19 \\
Corruption & 3.41 & 101 & 1.97 & 5.7 & 0.31 \\
Accountability & 5.53 & 111 & 1.05 & 8.97 & 1.17 \\
Bureaucracy & 6.73 & 72 & 3.31 & 5.51 & 0.10 \\
Total Index of Institution & 6.61 & 119 & 2.91 & 7.69 & 0.98 \\
\hline
\end{tabular}

Source: Authors own calculations. IIQ stands for institutional quality index; GR: Global Ranking. 


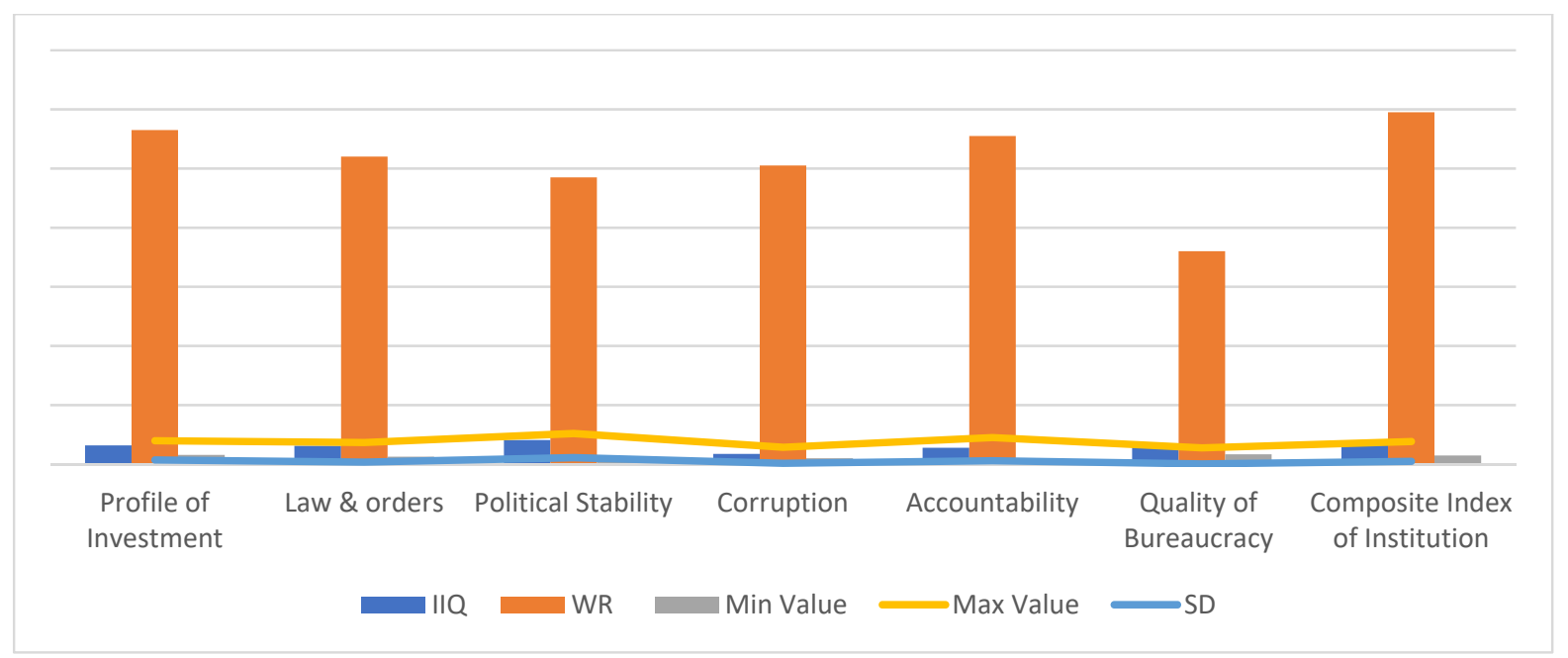

Figure 3. Indian quality of institution index (1980-2019). Source: Authors own calculations. IIQ stands for institutional quality index; GR: Global Ranking.

\section{Literature Review}

Many studies explored that poor institutions reduce FDI by discouraging the foreign investors [24-27]. This point of view is supported by [28] by pointing out three reasons for this: (i) firms' productivity is increased by good governance; (ii) the cost of production is increased by poor institutions; (iii) poor government performance increases uncertainty and risk, which leads to the higher vulnerability of firms. Different variables have been used for the measurement of institutional quality's impact on FDI inflow. Political risk is one of the proxies used for institutional quality. The authors of $[29,30]$ explored that political factors are very important for FDI inflows. François et al. (2020) found that more FDI is attracted in a democratic setup as compared to an authoritarian government. On the other hand, [25,31-33] found that FDI is insignificantly affected by political factors. Other factors for studying institutional quality impact on FDI are corruption and weak execution of the contract. Corruption was used by [26] for a proxy of institutional quality and found that FDI inflow is reduced by corruption. According to their study, poor institutional quality, i.e., in the economy where corruption level is high, leads to: (i) lack of transparency in the bureaucracy of the domestic country, which increases the investment opportunity cost; (ii) dealing with issues related to bureaucracy, high value is given to domestic partners; (iii) a decline in investor protectionism leads to decreasing their intangible assets; and (iv) in case of any dispute between any foreigner investor with his domestic business partner, he is biased toward local partners. The negative impact on FDI is confirmed by the study of [34]. The author of [35] concluded that corruption has no effect on FDI. The authors of [36] studied the impact of protectionism of property rights on the behavior pattern of multinational companies, and found that institutional performance was strongly correlated with the FDI ratio to total domestic investment. The property right importance for FDI attraction has been confirmed by the study of [37].

In [20], the impact of institutional quality on FDI in developing countries nations was estimated and a positive relationship was established between institutions and FDI, as well as the fact that foreign investors prefer to invest in countries with less diverse societies and political instability. The authors of [38] use corruption and the rule of law as measures of institutional quality to examine the impact of institutional quality on FDI inflows in developing and developed nations and find that institutions have a negligible impact on FDI inflows in developing countries due to their weak institutional structures. Furthermore, in developed countries, the institutional quality has a favorable and considerable impact on FDI. Other studies look at how institutions affect FDI inflows at different phases of development. As a result, strong quality institutions in the host country are a requirement for attracting FDI inflows. 
Efforts have been made by many researchers to combine various variables of institutional quality. The author of [39] analyzed different indicators and concluded that government performance, violence and political instability, rules of law, and regulatory burden have significant impact on FDI, and the voice of accountability factor is insignificant. The authors of [40], by utilizing data of World Bank, the Index of Environmental Sustainability, and the United Nations Development Program found that for inflow and outflow of FDI, governance infrastructure is one of the main variables. Data from the International Country Risk Guide (ICRG) used by [41] concluded that government performance, violence and political instability, rules of law, and regulatory burden have significant effect on FDI inflow. They found that as taxes increase, the cost of production increases, and in the same way, poor institution increases the business operational cost for foreign investor. Poor institution increases risk and uncertainty, which discourages overall investment, including FDI. For the location of FDI, the researchers used a range of institutional factors. First of all, they used a set of variables of institution developed by [42], such as transparency and accountability, non-violence, political stability, government control, no corruption, justice, and regulatory quality. Secondly, to the ICRG database indicator subset, expropriation of risk, government stability, no corruption, accountable democracy, and justice and law was added. Thirdly, the average responses of the country to the World Bank survey on the following determinants were used: (i) Courts quality; (ii) Amendments in rules, regulations, and laws; (iii) Federal government quality; and (iv) Corruption. They found that good quality institutions have a statistically significantly positive impact on FDI. Some institutional aspects have greater impact as compared to others. Unpredictable laws, absence of commitment, public policies, and extraordinary regulatory burden are important determinants of FDI. Latif [43] found FDI is positively affected by institutional quality. This study, for the first time, measured the institutional quality impact on FDI volatility. The study concluded that the existence of institutional determinants of FDI volatility was due to low economic growth, and recommended policy for FDI attraction in domestic economies by offering the "correct" macroeconomic atmosphere, which will not be effective without institutional reforms.

\section{Data and Research Methodology}

\subsection{Data Sources}

To evaluate the linkage between sectorial level FDI inflow and institutional quality during 1986-2019, we relied on the quality of institutions index (QI), a comprehensive constructed data index extracted from the International Country Risk Guide (ICRG). Our undermentioned QI comprised of six variables, such as investment profile, accountability, government stability, corruption, law and order, bureaucratic quality, and democratic values, to insure all the key extent and dimensions of QI. Indicators of Institutional quality are too correlated $[44,45]$ and including all variables in single equation is impossible [8]. So, $\mathrm{QI}$ is constructed by principal component analysis (PCA) method. The objective of using this method is to combine the six institutional quality indicators into a single variable, which duplicates the original data with minimum information loss. In order to devise the QI index, we utilized diverse statistical scales for selected institutional indicators in the original form of the time series datasets, and certain variables are time invariant. Hence, institutional quality indicator transformations make it time variant, which is more appropriate for time series data analysis. For compatibility of several methods, entire variables from 0-1 are rescaled in such a way that high values indicate strong institutional quality. In doing so, PCA is employed for weight adjustment (i.e., weight given to each factor in developing the QI index). The same technique was also used by [45] in the development of their economic freedom index. Data on primary sectors of FDI inflow (FDIPR), secondary sectors of FDI inflow (FDISR), services sectors of FDI inflow, and aggregated (FDI) inflow are gathered from India Statistical Yearbook 2019. We used two proxies (i.e., for trade openness (TOP), we used Merchandise export (measure in current USD)), and for domestic investment (DI), we used the data of gross fixed capital formation, and these two proxies' data are obtained 
from World Bank development indicators (WDI). Similarly, human capital index data are taken from the United Nations Development Program (UNDP). This study uses the infrastructure index (GINF), which comprises 30 indicators of qualitative and quantitative natures to cover all dimensions of infrastructure (both hard and soft), and an unobserved components model (UCM) is employed for the weight determination of each component in developing an index for infrastructure. Additionally, our infrastructure index contains four sub-indices such as energy, finance, communication, and transport. We used only the aggregated infrastructure index as a control variable. Details on the construction of this global infrastructure index are established in [46].

\subsection{Econometric Methodology}

Dynamic Autoregressive Distributed Lag Simulation model (SARDL) is an advanced form of orthodox ARDL, developed by [47]. There are several advantages of SARDL over the simple ARDL approach: (i) SARDL is used to overcome the issues in simple ARDL estimator for estimation in the long and short run. This novel model has the ability of stimulation, estimation, and robotic calculation of counterfactual adjustment in one explanatory variable and its effect on explained variables while keeping other control variables constant $[48,49]$. (ii) This model estimates, stimulates, and designs predicted graphs of negative and positive fluctuations in the indicators robotically, along with their statistical values of long- and short-run associations. (iii) SARDL estimates the symmetric and asymmetric shocks in the time series data while [22] the orthodox form of the ARDL procedure is restricted to the assessment of the linkage between dependent and independent variables in the long and short run. Furthermore, the study's indicators are integrated at their first difference, and levels are mixes of these two, which shows the suitability of the new SARDL model dynamic. The counterfactual adjustment is explanatory and their impact on explained variables are graphically displayed. Just as in previous studies [50-52], the empirical findings on the basis of this new dynamic ARDL error correction equations are presented below:

$$
\begin{array}{r}
\Delta \ln F D I=\alpha_{0 F D I}+\sum_{i=1}^{p} \psi_{i F D I} \Delta \ln F D I+\sum_{i=1}^{p} \phi_{i F D I} \Delta \ln I Q_{t-i}+\sum_{i=1}^{p} \delta_{i F D I} \Delta \ln T O P_{t-i}+\sum_{i=1}^{p} \omega_{i F D I} \Delta \ln H C A_{t-i} \\
+\sum_{i=1}^{p} \omega_{i F D I} \Delta \ln D I_{t-i}+\sum_{i=1}^{p} \theta_{F D I} \Delta \ln G I N F+\lambda_{1 F D I} \ln F D I_{t-1}+\lambda_{2 F D I} \ln I Q_{t-1} \\
+\lambda_{3 F D I} \ln T O P_{t-1}+\lambda_{4 F D I} \ln H C A_{t-1}+\lambda_{5 F D I} \ln D I_{t-1}+\lambda_{6 F D I} \ln G N I F_{t-1}+\mu_{1 t} \\
\Delta \ln Q I=\alpha_{0 Q I}+\sum_{i=1}^{p} \psi_{i Q I} \Delta \ln Q I+\sum_{i=1}^{p} \phi_{i Q I} \Delta \ln F D I_{t-i}+\sum_{i=1}^{p} \delta_{i Q I} \Delta \ln T O P_{t-i}+\sum_{i=1}^{p} \omega_{i Q I} \Delta \ln H C A_{t-i}+\sum_{i=1}^{p} \omega_{i Q I} \Delta \ln D I_{t-i} \\
+\sum_{i=1}^{p} \theta_{Q I} \Delta \ln G I N F+\lambda_{1 Q I} \ln F D I_{t-1}+\lambda_{2 Q I} \ln I Q_{t-1}+\lambda_{3 Q I} \ln T O P_{t-1}+\lambda_{4 Q I} \ln H C A_{t-1}+\lambda_{5 Q I} \ln D I_{t-1}+\lambda_{6 Q I} \ln G N I F_{t-1}
\end{array}
$$

Note: $\Delta$ indicates short run, $\ln$ shows natural $\log , \mu_{1}$ and $\mu_{2}$ represent error terms, $p$ shows variable lags, and $\lambda$ represents long run. In Equation (1), FDI shows aggregated and disaggregated foreign direct investment, IQ stand for foreign direct investment, TOP presents trade openness, DI explains domestic investment, GINF represents infrastructure index, and HCA displays human capital.

\section{Results and Discussions}

Before observing the bidirectional causality between sectorial FDI and institutional quality in India, it is substantial to check the stationary variables of the study and whether the variables are stationary at level or first difference. If not, then the empirical findings will be spurious. The results of the descriptive statistics of the study are presented in Table 2. To find out the integration order of the variables of our interest, two diverse unit root tests (i.e., augmented Dickey-Fuller (ADF) and Phillip-Perron (PP) tests) were utilized, which are shown in Table 3. Table 3 shows that all variables of the study are 
stationary and integrated either at level I(0) or first difference I(1), which clearly confirmed the new dynamic simulated ARDL model procedure, constructed by [47]. The SARDL model permits to choose the different lags for regressions and regressors. Table 4 reveals the structural break in the empirical results of the data from 1986 to 2019 . A structural break is an unstructured shock that has a long-term impact on the time series. Traditional testing would generally mistake the structural break for a unit root if this shock is not specifically taken into consideration [51,52]. As a result, the researchers utilized the Zivot-Andrew (ZA) unit root test, which is established after Zivot and Andrew [53]. The ZA test is a variant of the unit root test that assumes a breakpoint to be determined endogenously. As a result, the ZA test for unit root is compared to the trend's stationary process with a structural breakpoint in slope and intercept.

Table 2. Descriptive statistics.

\begin{tabular}{cccccc}
\hline Variables & Obs & Mean & St.Dev & Min & Max \\
\hline QI & 30 & 0.096 & 1.048 & -1.714 & 1.846 \\
FDIPR & 30 & 117.348 & 147.104 & -3.689 & 564.13 \\
FDISR & 30 & 647.094 & 346.24 & 119.69 & 1483.40 \\
FDITR & 30 & 641.273 & 997.95 & -183.10 & 3859.50 \\
FDI & 30 & 1546.10 & 1482.788 & 271.90 & 5591 \\
TOP & 30 & 0.33 & 0.038 & 0.254 & 0.388 \\
HCA & 30 & 53.59 & 1.38 & 55.21 & 56.60 \\
DIN & 30 & -0.628 & 0.063 & -0.768 & -0.447 \\
GINF & 30 & -0.674 & 0.235 & -1.93 & -0.32 \\
\hline
\end{tabular}

Table 3. Results of unit root.

\begin{tabular}{ccccc}
\hline & \multicolumn{2}{c}{ ADF Test } & \multicolumn{2}{c}{ DF-GLS Test } \\
\hline Variables & $\mathbf{I}(\mathbf{0})$ & $\mathbf{I}(\mathbf{1})$ & $\mathbf{I}(\mathbf{0})$ & $\mathbf{I}(\mathbf{1})$ \\
\hline QI & -1.279 & $-4.395^{* * *}$ & 1.392 & $-5.128^{* * *}$ \\
FDIPR & $-5.689^{* * *}$ & $-5.344^{* * *}$ & $-5.892^{* * *}$ & $-5.351^{* * *}$ \\
FDISR & -1.483 & $-3.753^{* *}$ & -1.583 & $-3.935^{* * *}$ \\
FDITR & -2.551 & $-3.224^{* *}$ & -2.702 & $-3.368^{* * *}$ \\
FDI & -2.852 & $-3.362^{* *}$ & $-2.971^{*}$ & $-3.542^{* * *}$ \\
TOP & -2.402 & $-6.346^{* * *}$ & $-2.538^{* * *}$ & $-6.157^{* * *}$ \\
HCA & $-3.697^{* *}$ & $-4.425^{* * *}$ & -2.583 & $-4.948^{* * *}$ \\
DIN & $-5.578^{* * *}$ & $-6.383^{* * *}$ & $-5.803^{* * *}$ & $-6.38^{* * *}$ \\
GINF & -1.982 & $-5.358^{* * *}$ & -1.542 & $-5.483^{* * *}$ \\
\hline
\end{tabular}

${ }^{*}, * *, * * *$ signifies $10 \%, 5 \%$, and $1 \%$ significance levels, respectively.

Table 4. Zivot-Andrews results.

\begin{tabular}{ccccc}
\hline Variables & $\mathbf{I}(\mathbf{0})$ & Break & $\mathbf{I}(\mathbf{1})$ & Break \\
\hline QI & -2.54 & 2005 & $-4.94^{* * *}$ & 2000 \\
FDIPR & $-6.345^{* * *}$ & 2003 & $-6.47^{* * *}$ & 2008 \\
FDISR & -2.73 & 2010 & $-4.54^{* *}$ & 2007 \\
FDITR & -3.45 & 2008 & $-5.29^{* * *}$ & 2006 \\
FDI & -3.25 & 2008 & $-5.41^{* * *}$ & 2012 \\
TOP & -3.11 & 2013 & $-6.52^{* * *}$ & 2006 \\
HCA & -2.63 & 1998 & $-4.71^{* *}$ & 2006 \\
DIN & $-5.92^{* * *}$ & 2009 & $-6.29^{* * *}$ & 2012 \\
GINF & -2.75 & 2003 & $-4.52^{* *}$ & 2010 \\
\hline
\end{tabular}

**, *** signifies $10 \%, 5 \%$, and $1 \%$ significance levels, respectively.

Table 4 demonstrates that, with the exceptions of $\operatorname{lnIQ}$ and $\operatorname{lnDIN}$, all of the selected variables have no unit roots in their levels, according to the ZA structural break unit root test results. The structural breaks, i.e., 2000, 2008, 2006, 2007, 2012, 2010, are reported in the indicator series such as institutional quality, disaggregated and aggregated FDI, 
human capital, trade openness, and infrastructure index, respectively. The majority of the breakdowns occurred between 2000 and 2012. This could be due to India's external sector's globalization and opening up its economy to the rest of the globe in the 2000s. Furthermore, the structural shift in 2006 can be justified by the fact that India's trade policy underwent the most significant change in that year. Similarly, the structural change in 2008 can be justified on the grounds of financial crises across the globe. Table 2 shows, however, that all of the variables listed below are stationary at first difference I(1).

The short-run estimate and analysis evaluates the immediate influence of an explanatory variable change on the dependent variable, whereas the long-run estimation and analysis evaluates and measures the reaction and speed of adjustment from short-run disequilibrium to long-run equilibrium. For the purposes of this study, the Wald test is used to search for long-term and short-term asymmetry in all variables (see Table 5). In addition, the Wald test is used in this analysis to reveal the long-run asymmetric interaction and its importance. An advantage of the Wald test over the other two is that it only requires the estimation of the unrestricted model, which lowers the computational burden as compared to the likelihood-ratio test. We used the ARDL bound test for evaluating long-run associations in selected variables of the study, prior to examining the statistical results of the simulated dynamic ARDL bound test. The decision of rejection or acceptance of the hypothesis (i.e., both null and alternative) is based on estimated F-statistic values. The presence of a long-run linkage in the study's variables is detected if the estimated F-statistic values are more than lower bound's values [22]. If the estimated value of the F-statistics Narayan [54] suggested that the critical values narrated by Pesaran [21] are applicable in case of large sample size only; in case of small sample size, it is not applicable) are between the upper and lower values, then the decision will be ambiguous. The ARDL approach is comparatively more convenient than other time series techniques [22]. A simple ARDL estimator can be employed when indicators of the study are stationary at level I $(0)$ or first difference (1). For the empirical analysis of our indicators, several lags are applies for regressors and regressions. In our empirical findings, the ARDL bound test indicates the existence of cointegration amongst selected variables shown in Table 5.

Table 5. ARDL cointegration bounds test and ECT (-1).

\begin{tabular}{|c|c|c|c|c|c|c|c|c|}
\hline \multicolumn{9}{|c|}{ QI to Aggregated and Disaggregated FDI } \\
\hline \multirow[b]{2}{*}{ Variables } & \multicolumn{2}{|c|}{$\begin{array}{c}\text { FDI } \\
{[1]}\end{array}$} & \multicolumn{2}{|c|}{$\begin{array}{c}\text { FDISR } \\
{[2]}\end{array}$} & \multicolumn{2}{|c|}{$\begin{array}{c}\text { FDIPR } \\
{[3]}\end{array}$} & \multicolumn{2}{|c|}{$\begin{array}{c}\text { FDITR } \\
{[4]}\end{array}$} \\
\hline & F-stat & ECT & F-Stat & ECT & F-Stat & ECT & F-Stat & ECT \\
\hline FDI/QI & $4.84 *$ & -2.13 & 2.38 & -2.11 & $7.49^{* * *}$ & -2.49 & $7.67^{* *}$ & -2.80 \\
\hline FDI/QI/GINF & 3.08 & -2.35 & 1.75 & -3.55 & $5.67^{* *}$ & -2.51 & $5.27^{* *}$ & -2.91 \\
\hline FDI/QI/GINF/HCA & $3.86^{*}$ & $-6.21^{* * *}$ & 3.31 & $-5.58^{* * *}$ & $12.51^{* * *}$ & $-6.14^{* *}$ & 2.95 & -4.19 \\
\hline FDI/QI/GINF/HCA/TOP & $11.8^{* * *}$ & $-8.75^{* * *}$ & $8.61^{* * *}$ & $5.42^{* * *}$ & $9.54^{* * *}$ & $-6.16^{* *}$ & $4.43^{* *}$ & $-7.31 * *$ \\
\hline FDI/QI/GINF/HCA/TOP/DI & $7.25 * * *$ & $-9.2^{* * *}$ & $-9.67^{* * *}$ & $4.05 *$ & $4.14 *$ & $-6.16^{* * *}$ & $5.61^{* * *}$ & $-7.35^{* * *}$ \\
\hline
\end{tabular}

The results in Tables 5 and 6 show the estimated ARDL bound values. The estimated values of the F-statistics are greater than upper bound values at $2.5 \%, 10 \%$, and $5 \%$ levels of significance for all the indicators of the study. The Wald-based bound test's estimated results are in Tables 5 and 6 for long-run association. The variables, including infrastructure, institutional quality, human capital index, trade openness, and domestic investment, are introduced gradually to the cointegration analysis of the relationship between sectorial FDI and institutional quality in India. The estimated F-statistic shows significant values in Tables 5 and 7, so alternative hypothesis (H1) is accepted, and the null hypothesis (Ho) is rejected. These empirical findings reveal a potential long-run linkage between institutional quality and sectorial-level FDI inflows. In addition to the main variables are the control variables of domestic investment, infrastructure, trade openness, and human capital index in sectorial FDI and institutional quality in India. These results approve the outcomes 
of $[48,55]$. The introduction of infrastructure, domestic investment, human capital index, and trade openness to the Equations (1) and (2) considerably improved the model's power.

Table 6. ARDL cointegration bounds test and ECT (-1).

\begin{tabular}{|c|c|c|c|c|c|c|c|c|}
\hline \multirow[b]{3}{*}{ Variables } & \multicolumn{6}{|c|}{ Aggregated and Disaggregated FDI to QI } & & \\
\hline & \multicolumn{2}{|c|}{$\begin{array}{c}\text { FDI } \\
{[1]}\end{array}$} & \multicolumn{2}{|c|}{$\begin{array}{c}\text { FDISR } \\
\text { [2] }\end{array}$} & \multicolumn{2}{|c|}{$\begin{array}{c}\text { FDIPR } \\
\text { [3] }\end{array}$} & \multicolumn{2}{|c|}{$\begin{array}{c}\text { FDITR } \\
\text { [4] }\end{array}$} \\
\hline & F-Stat & ECT & F-Stat & ECT & F-Stat & ECT & F-Stat & ECT \\
\hline QI/FDI & $8.32 * * *$ & $-0.78^{* * *}$ & $7.49^{* *}$ & -0.28 & 3.48 & -0.37 & 3.48 & -0.28 \\
\hline QI/FDI/GINF & $5.51 * *$ & $-0.78 * * *$ & $4.86 * *$ & -0.24 & 2.26 & -0.38 & 2.26 & -0.34 \\
\hline QI/FDI/GINF/HCA & $4.37^{* *}$ & $-0.82^{* * *}$ & $3.82 *$ & $-0.46^{* * *}$ & 2.16 & $-0.68^{* * *}$ & 2.13 & $-0.26^{* *}$ \\
\hline QI/FDI/GINF/HCA/TOP & $3.62 * *$ & $-0.73^{* * *}$ & $3.72 *$ & $-0.49^{* * *}$ & $3.9 * *$ & $-0.73^{* * *}$ & $3.99 * *$ & $-0.37^{* *}$ \\
\hline QI/FDI/GINF/HCA/TOP/DIN & 4.94 & $-0.64^{* * *}$ & $4.71^{* *}$ & $-0.47^{* * *}$ & $3.42 *$ & $-0.72^{* * *}$ & 2.09 & $-0.46^{* *}$ \\
\hline
\end{tabular}

$*, * *, * * *$ signifies $10 \%, 5 \%$, and $1 \%$ significance levels, respectively.

Table 7. Diagnostic tests.

\begin{tabular}{ccccc}
\hline Econometric Issues & Test Names & F-Statistics & $p$-Values & $\begin{array}{c}\text { Null-Hypothesis } \\
\text { Accepted/Rejected }\end{array}$ \\
\hline Heteroscedasticity & Breusch-Pagan-Godfrey & 0.261 & 0.642 & Accepted \\
\hline Serial Correlation & Breusch-Godfrey LM & 0.796 & 0.478 & Accepted \\
\hline Normality & Jarque-Bera & 4.773 & 0.219 & Accepted Equation $(1)$ \\
\hline Specification & Ramsey RESET & 2.544 & 0.142 & Accepted \\
\hline Heteroscedasticity & Breusch-Pagan-Godfrey & 2.165 & 0.615 & Accepted \\
\hline Serial Correlation & Breusch-Godfrey LM & 2.942 & 0.340 & Accepted \\
\hline Normality & Jarque-Bera & 0.108 & 0.831 & Accepted \\
\hline Specification & Ramsey RESET & 0.137 & 0.756 & Accepted
\end{tabular}

We performed several econometrics tests (such as the Breush-Godfrey LM test for serial or autocorrelation problems, the Breusch -Pagan-Godfrey for heteroscedasticity, JarqueBera for examination of the normal distribution of the selected time series data, and Ramsey RESET for specification problem). The empirical results of the mentioned tests are shown in Table 7 . These econometrics tests were employed for robustness and reliability checks in the given model. The Breusch-Godfrey LM test's empirical result suggest that the model is free from serial correlations issue. The empirical results of the Breusch-Pagan-Godfrey test shows that the models are free of heteroscedasticity problems. The Ramsey RESET test results suggest the correct specification good fit of the model. Finally, the Jarque-Bera test reveals that the residuals of the present models are normally distributed. The CUSUM test is presented in Figures 4 and 5, which shows that the selected models are stable.

Although long-run association is a necessary condition, it is not sufficient for finding a causal relationship among variables $[52,55]$. The variables' long-run relationship affirms that, at least, there must be unidirectional causality between the study's variables without indicating causality direction [43]. So, we estimate VECM for the identification of the direction of the short-run and long-run causal relationships between institutional quality and FDI. The granger causality test results presented in Table 8 reveal the long-run and short-run causalities from aggregated FDI to institutional quality. The results show significant coefficients of error correction terms (EC) when FDI, FDIPR, FDISR, and FDITR are used as regression variables. Reversely, ECT is also significant when QI is used as a regression variable (see Table 8, lower part). From these results, it is suggested that long-run causality exists from QI to FDI and also from FDI (aggregated and disaggregated) to QI, which confirms that institutional quality is important for FDI attraction in primary, services, and secondary sectors in India. 


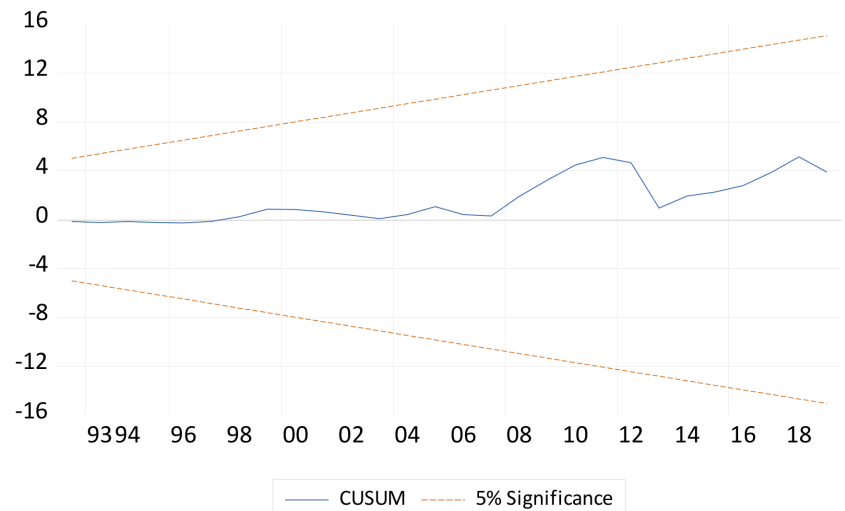

Figure 4. CUSUM test (FDI to Institutional Quality).

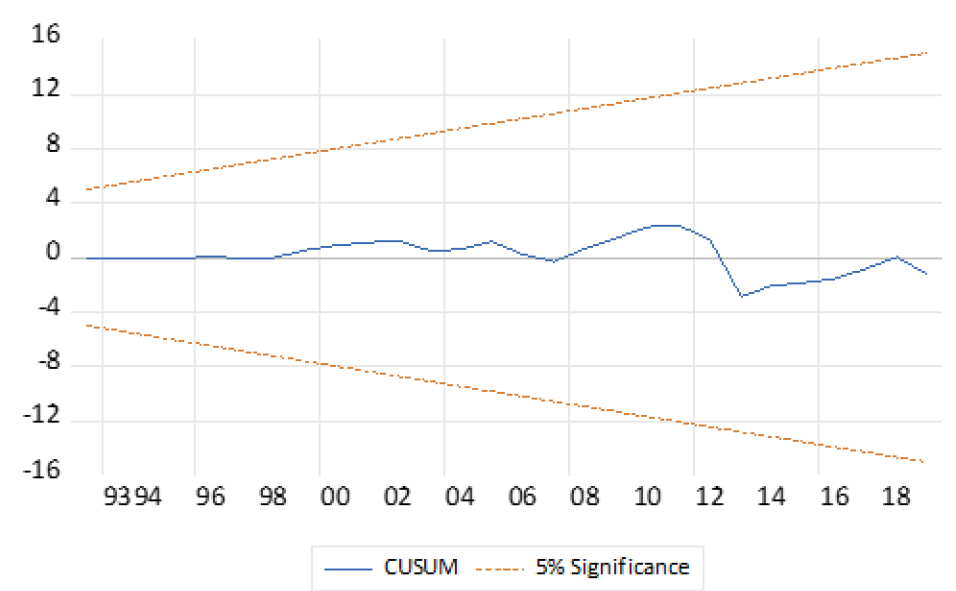

Figure 5. CUSUM test (Institutional Quality to FDI).

The empirical findings of the simulated ARDL dynamic model are presented in Table 9. The simulated ARDL dynamic model is helpful in stimulation, estimation, and designing for forecasting positive and negative variations graphs in variables automatically without losing their short- and long-run coefficients (see Figure 6). All these are the priorities of the new simulated ARDL dynamic model over the classical ARDL procedure because the orthodox ARDL version is capable of assessing the short-run and long-run associations of variables of study [56-58]. The statistical findings of the simulated ARDL dynamic model are displayed in Table 9. Table 9's statistical results established that institutional quality significantly positively affects aggregated and disaggregated FDI inflows in the short and long run in the Indian economy. The current empirical results are in line with the idea that institutional quality is interesting for foreign investors because it decreases the implementation cost and makes doing business easy in host countries. Meanwhile, inadequate institutions impede FDI, and its effects are similar to a tax, increasing FDI opportunity cost [7]. Investors are unwilling to invest in a country that has poor institutional quality where there is a culture of red tape, nepotism, and corruption because these factors increase business operational costs $[9,48,55]$. The results of other regressors, i.e., infrastructure, domestic investment, human capital, and trade openness, increase FDI in all sectors such as the primary, secondary, and services sectors in the short run and long run in India. These results are in line with those of $[48,54]$. 
Table 8. Results of Granger causality test.

\begin{tabular}{|c|c|c|c|c|c|c|c|c|c|}
\hline $\begin{array}{l}\text { Dependent } \\
\text { Variables }\end{array}$ & \multicolumn{4}{|c|}{ Short Run (F-Stat) } & \multicolumn{4}{|c|}{ Long Run (ECT) } & $\begin{array}{c}\text { Status } \\
\text { H1 }\end{array}$ \\
\hline \multicolumn{10}{|c|}{ Aggregated FDI to QI } \\
\hline & D.QI & D.GINF & D.HCA & D.TOP & QI & GINF & HCA & TOP & Accepted \\
\hline DFDI & 0.33 & 2.27 & $7.497^{* * *}$ & 0.47 & $-0.27^{* * *}$ & $-0.45^{* * *}$ & $-0.44^{* * *}$ & $-0.27^{* * *}$ & Accepted \\
\hline \multicolumn{10}{|c|}{ FDIPR to QI } \\
\hline DFDI & 0.035 & 0.67 & $0.951^{* * *}$ & 0.043 & $-0.87^{* * *}$ & $-0.83^{* * *}$ & $-0.80^{* * *}$ & $-0.88^{* * *}$ & Accepted \\
\hline \multicolumn{10}{|c|}{ FDISR to QI } \\
\hline DFDI & 1.41 & 1.11 & $4.51^{* * *}$ & $2.58 *$ & $-0.12 * *$ & $-0.13^{* *}$ & $-0.38^{* * *}$ & $-0.17^{* *}$ & Accepted \\
\hline \multicolumn{10}{|c|}{ FDITR to QI } \\
\hline DFDI & 0.77 & 1.95 & 1.53 & 0.28 & $-0.30^{* * *}$ & $-0.27^{* * *}$ & $-0.52^{* * *}$ & $-0.28^{* * *}$ & Accepted \\
\hline \multicolumn{10}{|c|}{ QI to Aggregated FDI (Reverse Causality) } \\
\hline & D.FDI & D.QI & D.HCA & D.TOP & FDI & QI & HCA & TOP & \\
\hline DQI & $5.98^{* * *}$ & 0.49 & $3.65^{* *}$ & 0.09 & $-0.17^{* * *}$ & $-0.25^{* * *}$ & $-0.15^{* * *}$ & $0.18^{* * *}$ & Accepted \\
\hline \multicolumn{10}{|c|}{ QI to FDIPR (Reverse Causality) } \\
\hline DQI & $2.23 *$ & 0.45 & 0.49 & $3.81^{* *}$ & $-0.91^{* * *}$ & $0.92^{* * *}$ & $0.95^{* * *}$ & $0.94^{* * *}$ & Accepted \\
\hline \multicolumn{10}{|c|}{ QI to FDISR (Reverse Causality) } \\
\hline DQI & 1.48 & 0.25 & $4.51 * * *$ & 0.88 & $0.51^{* * *}$ & $0.34^{* * *}$ & $-0.85^{* * *}$ & $-0.43^{* * *}$ & Accepted \\
\hline \multicolumn{10}{|c|}{ QI to FDITR (Reverse Causality) } \\
\hline DQI & 1.06 & 2.13 * & 0.41 & $2.35 *$ & $-0.27^{* * *}$ & $-0.36^{* * *}$ & $-0.37^{* * *}$ & $-0.56^{* * *}$ & Accepted \\
\hline
\end{tabular}

Table 9. Asymmetric impact of QI on disaggregated and aggregated FDI.

\begin{tabular}{|c|c|c|c|c|}
\hline Variables & $\begin{array}{c}\text { FDI } \\
{[1]}\end{array}$ & $\begin{array}{c}\text { FDIPR } \\
\text { [2] }\end{array}$ & $\begin{array}{c}\text { FDISR } \\
\text { [3] }\end{array}$ & $\begin{array}{c}\text { FDITR } \\
\text { [4] }\end{array}$ \\
\hline \multicolumn{5}{|c|}{ Short run Dynamics } \\
\hline $\operatorname{lnFDI}$ & $\begin{array}{c}0.421 \text { ** } \\
(0.015)\end{array}$ & $\begin{array}{c}0.164 \\
(0.285)\end{array}$ & $\begin{array}{c}0.138 \\
0.163)\end{array}$ & $\begin{array}{c}0.201 \\
(0.341)\end{array}$ \\
\hline $\ln Q \mathrm{I}$ & $\begin{array}{l}0.214^{* *} \\
(0.042)\end{array}$ & $\begin{array}{c}0.101 \\
(0.295)\end{array}$ & $\begin{array}{c}0.393 \\
0.274)\end{array}$ & $\begin{array}{c}0.458 \\
(0.528)\end{array}$ \\
\hline $\ln \mathrm{HCA}$ & $\begin{array}{l}5.58^{* * *} \\
(1.523)\end{array}$ & $\begin{array}{l}1.302 * * \\
(0.852)\end{array}$ & $\begin{array}{l}7.34^{* * *} \\
(2.624)\end{array}$ & $\begin{array}{l}-8.83^{*} \\
(3.725)\end{array}$ \\
\hline $\ln \mathrm{TOP}$ & $\begin{array}{l}6.47^{* * *} \\
(1.528)\end{array}$ & $\begin{array}{c}11.29 \\
(14.842)\end{array}$ & $\begin{array}{c}3.182 \\
(2.264)\end{array}$ & $\begin{array}{c}5.472 \\
(6.725)\end{array}$ \\
\hline $\operatorname{lnGINF}$ & $\begin{array}{l}3.47^{* * *} \\
(0.328)\end{array}$ & $\begin{array}{c}3.685 \\
(3.716)\end{array}$ & $\begin{array}{c}8.263 \\
(9.625)\end{array}$ & $\begin{array}{c}6.581^{* * *} \\
(3.872)\end{array}$ \\
\hline $\operatorname{lnDI}$ & $\begin{array}{c}-3.68^{* *} \\
(1.625)\end{array}$ & $\begin{array}{c}-2.79 \\
(3.726)\end{array}$ & $\begin{array}{c}12.64 \\
(13.924)\end{array}$ & $\begin{array}{c}-11.51 \\
(9582)\end{array}$ \\
\hline \multicolumn{5}{|c|}{ Long run Dynamics } \\
\hline $\operatorname{lnFDI}$ & $\begin{array}{c}0.689 \text { ** } \\
(0.062)\end{array}$ & $\begin{array}{l}0.207^{*} \\
(0.074)\end{array}$ & $\begin{array}{c}3.294^{* * *} \\
(0.973)\end{array}$ & $\begin{array}{c}1.504^{* * *} \\
(0.042)\end{array}$ \\
\hline $\ln I Q$ & $\begin{array}{c}-0.876 \text { ** } \\
(0.023)\end{array}$ & $\begin{array}{l}2.38^{* * *} \\
(0.528)\end{array}$ & $\begin{array}{c}10.27^{* * *} \\
(4.827)\end{array}$ & $\begin{array}{c}7.759 * * * \\
(5.826)\end{array}$ \\
\hline $\operatorname{lnGINF}$ & $\begin{array}{c}0.937 * * \\
(0.064)\end{array}$ & $\begin{array}{l}0.655^{*} \\
(0.924)\end{array}$ & $\begin{array}{l}0.386^{*} \\
(0.173)\end{array}$ & $\begin{array}{c}0.191 \\
(0.620)\end{array}$ \\
\hline $\operatorname{lnTOP}$ & $\begin{array}{l}4.35^{* *} \\
(1.623)\end{array}$ & $\begin{array}{c}10.58^{* * *} \\
(3.825)\end{array}$ & $\begin{array}{c}12.86^{* * *} \\
(6.74)\end{array}$ & $\begin{array}{c}10.37^{* * *} \\
(7.105)\end{array}$ \\
\hline $\operatorname{lnHCA}$ & $\begin{array}{l}35.53 * * \\
(18.726)\end{array}$ & $\begin{array}{l}10.35^{* *} \\
(5.104)\end{array}$ & $\begin{array}{l}47.47^{* * *} \\
(28.618)\end{array}$ & $\begin{array}{l}56.49^{* * *} \\
(10.815)\end{array}$ \\
\hline
\end{tabular}


Table 9. Cont.

\begin{tabular}{ccccc}
\hline Variables & FDI & FDIPR & FDISR & FDITR \\
& {$[1]$} & {$[2]$} & {$[3]$} & [4] \\
\hline lnDI & $1.36^{*}$ & $-0.83^{*}$ & 5.67 & -4.27 \\
& $(0.805)$ & $(0.091)$ & $(6.810)$ & $(3.326)$ \\
Constant & $-21.94^{* * *}$ & $-66.82^{* * *}$ & $-31.21^{* *}$ & $-43.53 * *$ \\
& $(3.917)$ & $(4.325)$ & $(6.160)$ & $(5.013)$ \\
\hline F - test PSS & $7.28^{* * *}$ & $3.27^{* *}$ & 1.21 & 2.85 \\
Observations & 34 & 34 & 34 & 34 \\
R Square Adj. & 0.901 & 0.932 & 0.893 & 0.912 \\
\hline & \multicolumn{3}{c}{0.013} \\
\hline Asymmetries SR & $0.412^{*}$ & Asymmetry statistic & $1.45^{*}$ & $1.92 *$ \\
Asymmetries LR & $5.23^{* * *}$ & $0.141^{*}$ & $1.93^{*}$ & 0.013 \\
\hline
\end{tabular}

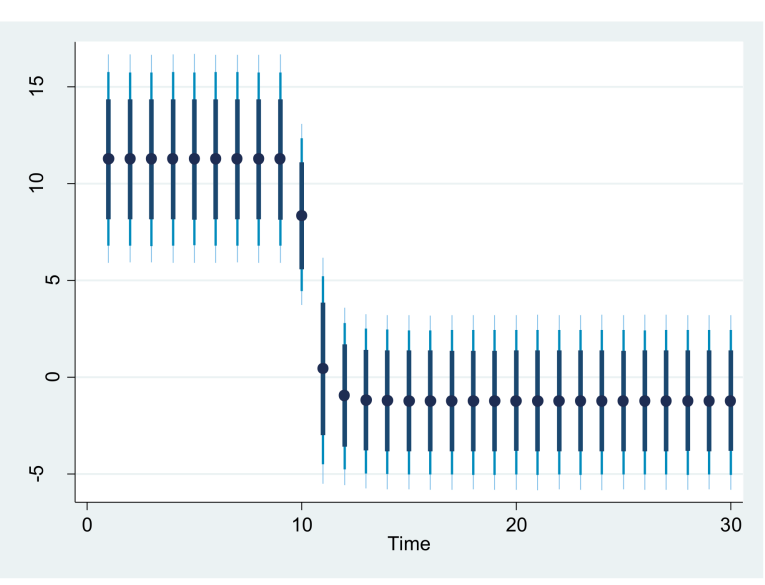

$-10 \% \operatorname{lnIQ}$

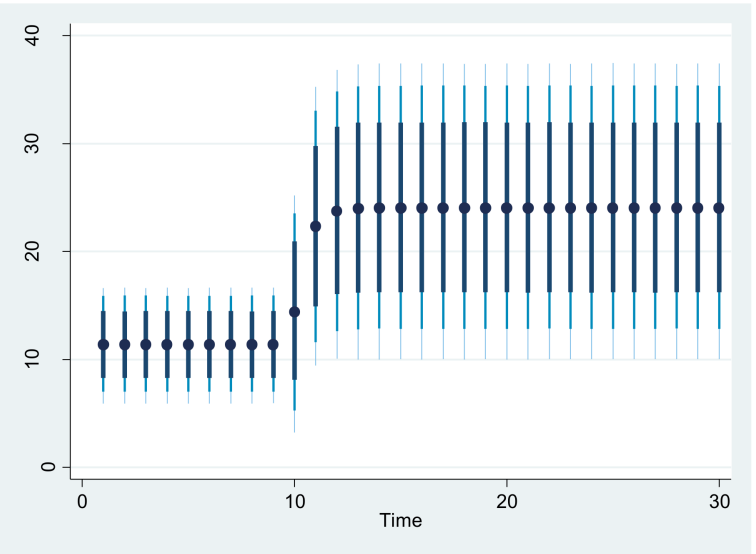

$-10 \% \operatorname{lnIQ}$

Figure 6. Response of FDI to $10 \% \pm$ shock in lnIQ.

Table 10 shows the effect of aggregated and disaggregated FDI on Indian institutional quality (see Figure 7). The empirical results of the study affirm that aggregated and disaggregated FDI inflows have significant positive effects on institutional quality in the long run. These empirical results are similar to the idea that FDI's positive role in economics has become a self-evident truth where technological, savings, and investment gaps are covered by foreign firms through the provision of technology and cash to the recipient economy. FDI provides opportunity to local firms for learning from foreign firms either by doing with these firms or watching and infuse a sense of competition in local firms and institutions, which boosts host country productivity. In [13], it is suggested that competition in attracting FDI has positive contributions in FDI-aspirant countries and call for prodigious positive change of FDI and introduce to rival recipient countries a 'race to the top'. FDI not only transfers innovation in productive technology, but it also improves the institutional quality, which contributes to the domestic economy [59]. These consequences are the most obvious in economies with low tolerance for corruption and informal business activity [34]. The results of other control variables, i.e., human capital, domestic investment, infrastructure, and trade openness have significant positive effects on institutional quality. This effect is often dual, especially regarding the trade openness and institutional factors affecting the credit cycles and trade dynamics, respectively [56,57]. These results are in line with [59] in the long run and short run for China. The same findings are also typical for developing countries with their patterns of human capital and investment potential changes influenced by institutional environment quality [45]. 
Table 10. Asymmetric impact of QI on disaggregated and aggregated FDI.

\begin{tabular}{|c|c|c|c|c|}
\hline Variables & $\begin{array}{c}\text { FDI } \\
\text { [1] }\end{array}$ & $\begin{array}{c}\text { FDIPR } \\
\text { [2] }\end{array}$ & $\begin{array}{c}\text { FDISR } \\
{[3]}\end{array}$ & $\begin{array}{c}\text { FDITR } \\
{[4]}\end{array}$ \\
\hline \multicolumn{5}{|c|}{ Short run Dynamics } \\
\hline $\operatorname{lnFDI}$ & $\begin{array}{l}0.421 * * \\
(0.015)\end{array}$ & $\begin{array}{c}0.164 \\
(0.285)\end{array}$ & $\begin{array}{c}0.138 \\
0.163)\end{array}$ & $\begin{array}{c}0.201 \\
(0.341)\end{array}$ \\
\hline $\ln Q \mathrm{I}$ & $\begin{array}{c}0.214^{* *} \\
(0.042)\end{array}$ & $\begin{array}{c}0.101 \\
(0.295)\end{array}$ & $\begin{array}{c}0.393 \\
0.274)\end{array}$ & $\begin{array}{c}0.458 \\
(0.528)\end{array}$ \\
\hline $\operatorname{lnHCA}$ & $\begin{array}{l}5.58 * * * \\
(1.523)\end{array}$ & $\begin{array}{l}1.302 * * \\
(0.852)\end{array}$ & $\begin{array}{l}7.34^{* * *} \\
(2.624)\end{array}$ & $\begin{array}{l}-8.83 * \\
(3.725)\end{array}$ \\
\hline $\operatorname{lnTOP}$ & $\begin{array}{l}6.47^{* *} \\
(1.528)\end{array}$ & $\begin{array}{c}11.29 \\
(14.842)\end{array}$ & $\begin{array}{c}3.182 \\
(2.264)\end{array}$ & $\begin{array}{c}5.472 \\
(6.725)\end{array}$ \\
\hline $\operatorname{lnGINF}$ & $\begin{array}{l}3.47^{* * *} \\
(0.328)\end{array}$ & $\begin{array}{c}3.685 \\
(3.716)\end{array}$ & $\begin{array}{c}8.263 \\
(9.625)\end{array}$ & $\begin{array}{c}6.581^{* * *} \\
(3.872)\end{array}$ \\
\hline $\ln \mathrm{l} I$ & $\begin{array}{c}-3.68^{* *} \\
(1.625)\end{array}$ & $\begin{array}{r}-2.79 \\
(3.726) \\
\end{array}$ & $\begin{array}{c}12.64 \\
(13.924) \\
\end{array}$ & $\begin{array}{c}-11.51 \\
(9582)\end{array}$ \\
\hline \multicolumn{5}{|c|}{ Long run Dynamics } \\
\hline $\operatorname{lnFDI}$ & $\begin{array}{c}0.689 * * \\
(0.062)\end{array}$ & $\begin{array}{l}0.207^{*} \\
(0.074)\end{array}$ & $\begin{array}{c}3.294^{* * *} \\
(0.973)\end{array}$ & $\begin{array}{c}1.504^{* * *} \\
(0.042)\end{array}$ \\
\hline $\operatorname{lnIQ}$ & $\begin{array}{c}-0.876^{* *} \\
(0.023)\end{array}$ & $\begin{array}{l}2.38^{* * *} \\
(0.528)\end{array}$ & $\begin{array}{c}10.27^{* * * *} \\
(4.827)\end{array}$ & $\begin{array}{c}7.759^{* * * *} \\
(5.826)\end{array}$ \\
\hline $\operatorname{lnGINF}$ & $\begin{array}{c}0.937^{* *} \\
(0.064)\end{array}$ & $\begin{array}{l}0.655 * \\
(0.924)\end{array}$ & $\begin{array}{l}0.386^{*} \\
(0.173)\end{array}$ & $\begin{array}{c}0.191 \\
(0.620)\end{array}$ \\
\hline $\operatorname{lnTOP}$ & $\begin{array}{l}4.35 * * \\
(1.623)\end{array}$ & $\begin{array}{c}10.58^{* * *} \\
(3.825)\end{array}$ & $\begin{array}{c}12.86^{* * *} \\
(6.74)\end{array}$ & $\begin{array}{c}10.37^{* * *} \\
(7.105)\end{array}$ \\
\hline $\operatorname{lnHCA}$ & $\begin{array}{l}35.53 * * \\
(18.726)\end{array}$ & $\begin{array}{l}10.35 \text { ** } \\
(5.104)\end{array}$ & $\begin{array}{l}47.47^{* * *} \\
(28.618)\end{array}$ & $\begin{array}{l}56.49^{* * *} \\
(10.815)\end{array}$ \\
\hline $\ln \mathrm{l} I$ & $\begin{array}{c}1.36^{*} \\
(0.805)\end{array}$ & $\begin{array}{l}-0.83 * \\
(0.091)\end{array}$ & $\begin{array}{c}5.67 \\
(6.810)\end{array}$ & $\begin{array}{c}-4.27 \\
(3.326)\end{array}$ \\
\hline Constant & $\begin{array}{c}-21.94 * * * \\
(3.917)\end{array}$ & $\begin{array}{c}-66.82 * * * \\
(4.325)\end{array}$ & $\begin{array}{c}-31.21^{* * *} \\
(6.160)\end{array}$ & $\begin{array}{c}-43.53^{* * *} \\
(5.013)\end{array}$ \\
\hline $\mathrm{F}-$ test PSS & $7.28^{* * *}$ & $3.27 * *$ & 1.21 & 2.85 \\
\hline Observations & 34 & 34 & 34 & 34 \\
\hline R Square Adj. & 0.901 & 0.932 & 0.893 & 0.912 \\
\hline \multicolumn{5}{|c|}{ Asymmetry statistic } \\
\hline Asymmetries SR & $0.412 *$ & 0.141 * & $8.52^{* * *}$ & 0.013 \\
\hline Asymmetries LR & $5.23^{* * *}$ & $1.93 *$ & $1.45^{*}$ & 1.92 * \\
\hline
\end{tabular}




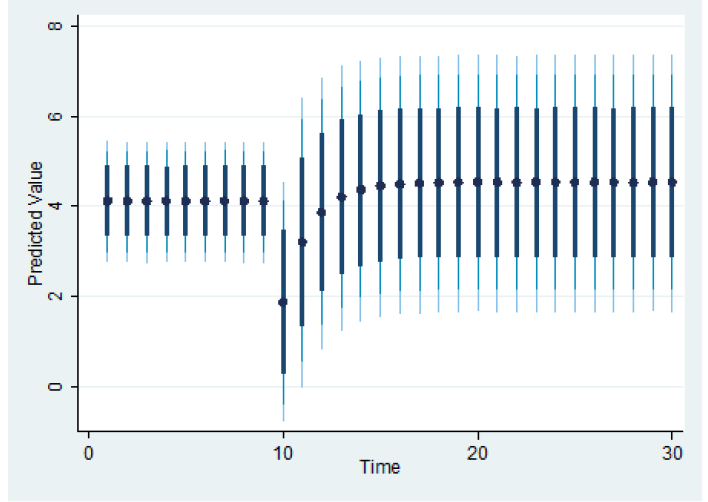

-10 aggregated FDI

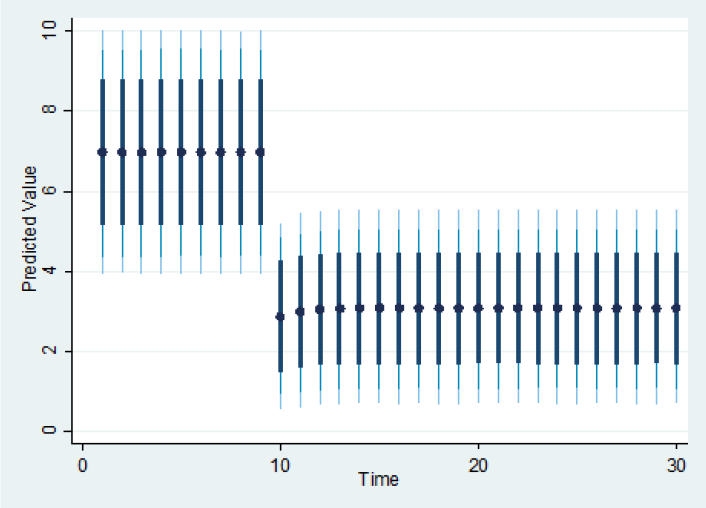

-10 aggregated FDI

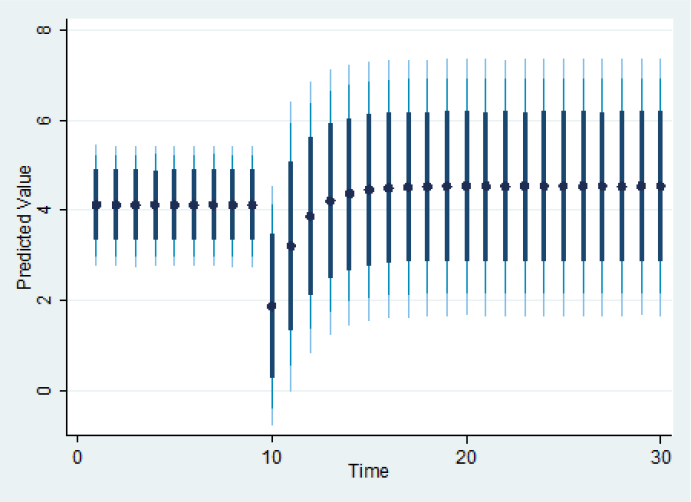

-10 aggregated FDI

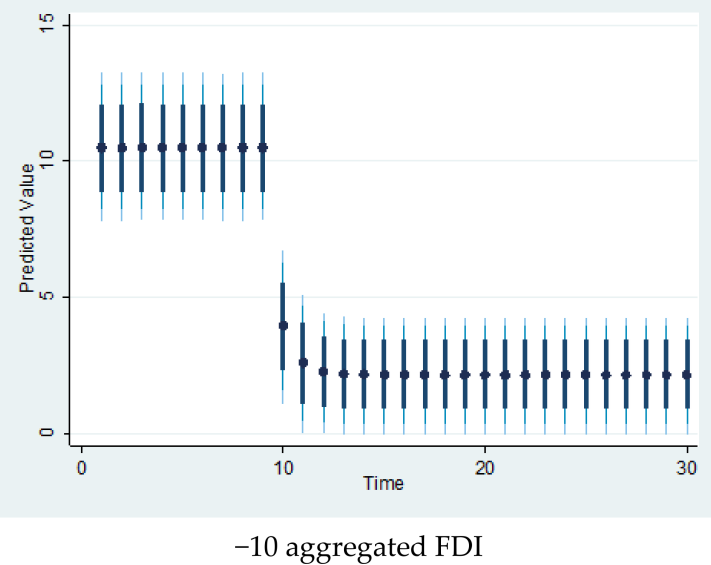

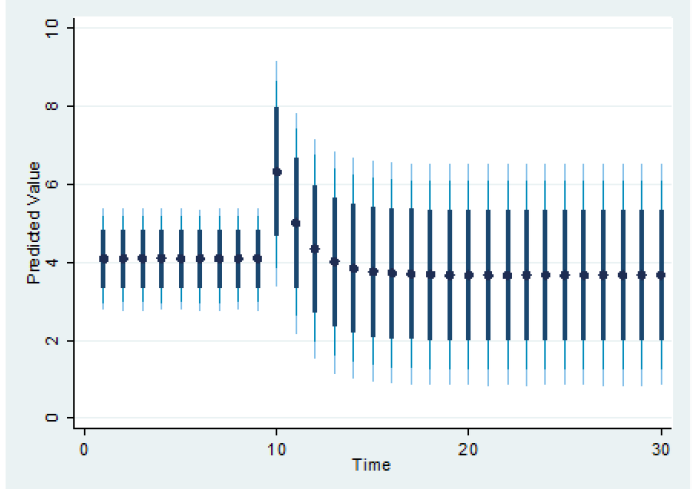

-10 aggregated FDI

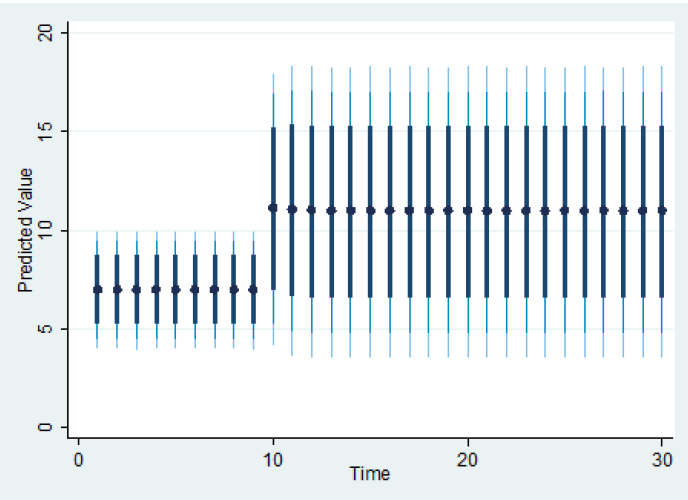

-10 aggregated FDI

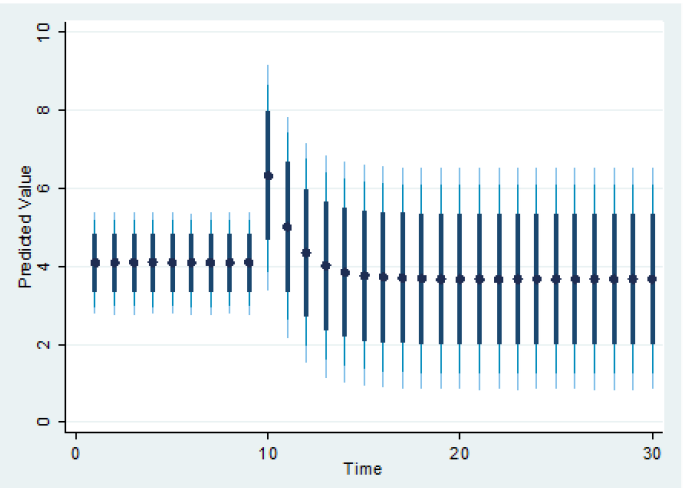

-10 aggregated FDI

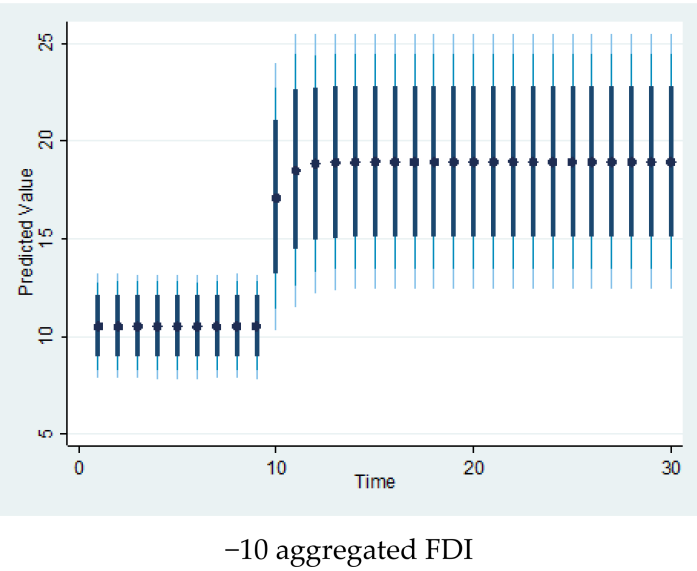

Figure 7. Response of institutional quality to $10 \% \pm$ shock in aggregated and disaggregated FDI, respectively. 


\section{Conclusions and Policy Implication}

Market connectivity is deteriorated by inadequate institutions, which create hurdles to trade potential, create frictions in markets, and impose unnecessary delays, and thus the overall cost of production is increased, which adversely affects FDI inflow in the home economy. The poor quality of institutions adversely affects the competitive edge of an economy, while the availability of good quality institutions improves its comparative advantage, both on international as well as on domestic fronts.

We used a new simulated ARDL dynamic approach on annual data from 1986-2019 to find out the long-run and short-run associations of institutional quality with FDI. The empirical results of the study affirm the existence of significant causal relationships between institutional quality and aggregated and disaggregated FDI inflow. The empirical outcome of the study suggests that the quality of institutions attracts FDI inflow in India (i.e., institutional quality has a significant and positive effect on aggregated and disaggregated FDI inflows in the short run and long run). Reversely, FDI inflow improves the quality of institutions (e.g., law and order, domestic accountability, investment profile, bureaucratic quality, political stability, and corruption). It is good news for policymakers in India who want to catch up to developed economies and to minimize the gap between India and developed economies, particularly in attracting FDI inflows. These empirical outcomes also negate the claim of [54] that Indian firms are independent of quality of domestic institutions. Rather, the results indicate that institutional quality is highly skill intensive and confident in India, and thus encouraging domestic firms' development would be an efficient way to improve FDI inflow rate. In addition to the main variables, the explanatory control variables such as infrastructure, domestic investment, trade openness, and human capital also have positive and significant effects on the aggregated and disaggregated FDI inflow and quality of institutions, which means reformed open policy for further development in institutional quality system is also important for the enhancement of FDI inflow in India.

Author Contributions: Conceptualization, F.U.R. and E.A.; methodology, F.U.R.; software, M.A.K., formal analysis M.A.K.; validation, E.A.; investigation, F.U.R. and Z.L.; resources, Z.L. and J.P.; data curation, F.U.R. and E.A.; writing - original draft preparation, F.U.R. and E.A.; writing - review and editing, M.A.K. and Z.L.; supervision, M.A.K. and Z.L.; project administration, M.A.K. and J.P.; funding acquisition, Z.L. and J.P. All authors have read and agreed to the published version of the manuscript.

Funding: This research received no external funding.

Institutional Review Board Statement: Not applicable.

Informed Consent Statement: Not applicable.

Data Availability Statement: The data used in present study may be made available on request to the corresponding authors.

Acknowledgments: We are very thankful to the Graduate School of Economics and Management, Ural Federal University, for technical support.

Conflicts of Interest: The authors declare no conflict of interest.

\section{References}

1. Rehman, F.U.; Ahmad, E.; Khan, M.; Popp, J.; Oláh, J. Does Trade Related Sectoral Infrastructure Make Chinese Exports More Sophisticated and Diversified? Sustainability 2021, 13, 5408. [CrossRef]

2. Fon, R.M.; Filippaios, F.; Stoian, C.; Lee, S.H. Does foreign direct investment promote institutional development in Africa? Int. Bus. Rev. 2021, 30, 101835. [CrossRef]

3. Contractor, F.J. The world economy will need even more globalization in the post-pandemic 2021 decade. J. Int. Bus. Stud. 2021, 1-16. [CrossRef] [PubMed]

4. Kottaridi, C.; Giakoulas, D.; Monolopoulos, D. Escapism FDI from developed Economies: The Role of Regulatory Context and Corporate Taxation. Int. Bus. Rev. 2019, 28, 36-47. [CrossRef]

5. Soh, K.L.; Wong, W.P.; Tang, C.F. The role of institutions at the nexus of logistic performance and foreign direct investment in Asia. Asian J. Shipp. Logist. 2021, 37, 165-173. [CrossRef] 
6. Azzimonti, M. Does partisan conflict deter FDI inflows to the US? J. Int. Econ. 2019, 120, 162-178. [CrossRef]

7. Camarero, M.; Moliner, S.; Tamarit, C. Japan's FDI drivers in a time of financial uncertainty. New evidence based on Bayesian Model Averaging. Jpn. World Econ. 2021, 57, 101058. [CrossRef]

8. Chen, D.; Yu, X.; Zhang, Z. Foreign direct investment comovement and home country institutions. J. Bus. Res. 2019, 95, $220-231$. [CrossRef]

9. Cicatiello, L.; De Simone, E.; Ercolano, S.; Gaeta, G.L. Assessing the impact of fiscal transparency on FDI inflows. Socio-Econ. Plan. Sci. 2021, 73, 100892. [CrossRef]

10. Wang, L.-H.; Lin, C.-H.; Fung, H.-G.; Kao, T.-C. Foreign direct investment and downside risk: Evidence from Taiwan. Pac.-Basin Financ. J. 2019, 57, 101114. [CrossRef]

11. Tang, R.W. Pro-market institutions and outward FDI of emerging market firms: An institutional arbitrage logic. Int. Bus. Rev. 2021, 30, 101814. [CrossRef]

12. Piteli, E.; Kafouros, M.; Pitelis, C.N. Follow the people and the money: Effects of inward FDI on migrant remittances and the contingent role of new firm creation and institutional infrastructure in emerging. J. World Bus. 2021, 56, 101178. [CrossRef]

13. Nam, J.; Bon Sesay, J.; Wynne, K.; Zhang, G. Financial efficiency and accounting quality: The impact of institutional micro-factors on FDI. J. Policy Model. 2020, 42, 451-465. [CrossRef]

14. François, A.; Panel, S.; Weill, L. Educated dictators attract more foreign direct investment. J. Comp. Econ. 2020, 48, 37-55. [CrossRef]

15. Challe, E.; Lopez, J.I.; Mengus, E. Institutional quality and capital inflows: Theory and evidence. J. Int. Money Financ. 2019, 96, 168-191. [CrossRef]

16. Antonietti, R.; Franco, C. From FDI to economic complexity: A panel Granger causality analysis. Struct. Chang. Econ. Dyn. 2021, 56, 225-239. [CrossRef]

17. Gu, J. FDI characteristics, industry homogeneity, and audit fees in Japanese multinationals. J. Multinatl. Financ. Manag. 2021, 61, 100678. [CrossRef]

18. Kellard, N.M.; Kontonikas, A.; Lamla, M.J.; Maiani, S.; Wood, G. Risk, financial stability and FDI. J. Int. Money Financ. 2020, 120, 102232. [CrossRef]

19. Slesman, L.; Abubakar, Y.A.; Mitra, J. Foreign direct investment and entrepreneurship: Does the role of institutions matter? Int. Bus. Rev. 2021, 30, 101774. [CrossRef]

20. Heavilin, J.; Songur, H. Institutional distance and Turkey's outward foreign direct investment. Res. Int. Bus. Financ. 2020, 54, 101299. [CrossRef]

21. Jordan, S.; Philips, A.Q. Cointegration testing and dynamic simulations of autoregressive distributed lag models. Stata J. 2018, 18, 902-923. [CrossRef]

22. Pesaran, M.H.; Shin, Y.; Smith, R.J. Bounds testing approaches to the analysis of level relationships. J. Appl. Econom. 2001, 16, 289-326. [CrossRef]

23. Reddy, K.S. Pot the ball? Sovereign wealth funds' outward FDI in times of global financial market turbulence: A yield institutions-based view. Cent. Bank Rev. 2019, 19, 129-139. [CrossRef]

24. Srivastava, S. The role of foreign direct investment in India's services exports: An empirical investigation. Singap. Econ. Rev. 2006, 51, 175-194. [CrossRef]

25. Asiedu, E.; Dynamics, A.V.-M. Discount factors and thresholds: Foreign investment when enforcement is imperfect. Macroecon. Dyn. 2000, 4, 1-21. [CrossRef]

26. Campos, J.; Lien, D.; Pradhan, S. The impact of corruption on investment: Predictability matters. World Dev. 1999, $27,1059-1067$. [CrossRef]

27. Gastanaga, V.; Nugent, J.B.; Pashamova, B. Host country reforms and FDI inflows: How much dif-ference do they make? World Dev. 1998, 26, 1299-1314. [CrossRef]

28. Liu, H.; Islam, M.; Khan, M.; Hosain, M.I.; Pervaiz, K. Does financial deepening attract foreign direct investment? Fresh evidence from panel threshold analysis. Res. Int. Bus. Financ. 2020, 53, 101198. [CrossRef]

29. Aust, V.; Morais, A.I.; Pinto, I. How does foreign direct investment contribute to Sustainable Development Goals? Evidence from African countries. J. Clean. Prod. 2020, 245, 118823. [CrossRef]

30. Ali, F.; Fiess, N.; MacDonald, R. Climbing to the top? Foreign direct investment and property rights. Econ. Inq. 2010, 49, 289-302. [CrossRef]

31. Ades, A.; Di Tella, R. Rents, Competition, and Corruption. Am. Econ. Rev. 1999, 89, 982-993. [CrossRef]

32. Ahmad, M.; Alam, S.; Butt, M.; Haroon, Y. Foreign direct investment, exports, and domestic output in Pakistan. Pak. Dev. Rev. 2003, 42, 715-723. [CrossRef]

33. Alfaro, L.; Kalemli-Ozcan, S.; Volosocych, V. Capital Flows in a Globalized World: The Role of Policies and Institutions. In Capital Controls and Capital Flows in Emerging Economies: Policies, Practices, and Consequences; University of Chicago Press: Chicago, IL, USA, 2007; pp. 19-72.

34. Fuentelsaz, L.; Garrido, E.; Maicas, J.P. The effect of informal and formal institutions on foreign market entry selection and performance. J. Int. Manag. 2020, 26, 100735. [CrossRef]

35. Jung, J. Institutions and Telecommunications Investment. Inf. Econ. Policy 2020, 50, 100849. [CrossRef]

36. Lakshmi, G.; Saha, S.; Bhattarai, K. Does corruption matter for stock markets? The role of heterogeneous institutions. Econ. Model. 2021, 94, 386-400. [CrossRef] [PubMed] 
37. Athreye, S.; Saeed, A.; Baloch, M.S. Financial crisis of 2008 and outward foreign investments from China and India. J. World Bus. 2021, 56, 101190. [CrossRef]

38. Buchanan, B.G.; Le, Q.V.; Rishi, M. Foreign direct investment and institutional quality: Some empirical evidence. Int. Rev. Financ. Anal. 2012, 21, 81-89. [CrossRef]

39. Bhagwati, J.N. In Defence of Globalization; Oxford University Press: Oxford, UK, 2007.

40. Globerman, S.; Shapiro, D. Global Foreign Direct Investment Flows: The Role of Governance Infrastructure. World Dev. 2002, 30, 1899-1919. [CrossRef]

41. Uddin, M.; Chowdhury, A.; Zafar, S.; Shafique, S.; Liu, J. Institutional determinants of inward FDI: Evidence from Pakistan. Int. Bus. Rev. 2019, 28, 344-358. [CrossRef]

42. Dang, D.A. How foreign direct investment promote institutional quality: Evidence from Vietnam. J. Comp. Econ. 2013, 41, 1054-1072. [CrossRef]

43. Abdel-Latif, H. FDI response to political shocks: What can the Arab Spring tell us? J. Behav. Exp. Financ. 2019, 24, 100233. [CrossRef]

44. Zhang, M.; Li, G.; Mu, H.L.; Ning, Y.D. Energy and energy efficiencies in the Chinese transportation sector, 1980-2009. Energy 2011, 36, 770-776. [CrossRef]

45. Rehman, F.U.; Noman, A.A.; Ding, Y. Does infrastructure increase exports and reduce trade deficit? Evidence from selected South Asian countries using a new Global Infrastructure Index. J. Econ. Struct. 2020, 9, 1-23. [CrossRef]

46. Rehman, F.; Ding, Y.; Noman, A.A.; Khan, M.A. The nexus between infrastructure and export: An empirical evidence from Pakistan. Glob. J. Emerg. Mark. Econ. 2020, 12, 141-157. [CrossRef]

47. Jordan, S.; Philips, A.Q. Dynamic simulation and testing for single-equation cointegrating and stationary autoregressive distributed lag models. $R$ J. 2019, 10, 469. [CrossRef]

48. Sarkodie, S.; Strezov, V.; Weldekidan, H.; Asamoah, E.F.; Owusu, P.A.; Doyi, I.N.Y. Environmental sustainability assessment using dynamic autoregressive-distributed lag simulations-Nexus between greenhouse gas emissions, biomass energy. Sci. Total Environ. 2019, 668, 318-332. [CrossRef] [PubMed]

49. Khan, M.A.; Ahmed, M.; Popp, J.; Oláh, J. US Policy Uncertainty and Stock Market Nexus Revisited through Dynamic ARDL Simulation and Threshold Modelling. Mathematics 2020, 8, 2073. [CrossRef]

50. Ketteni, E.; Kottaridi, C. The impact of regulations on the FDI-growth nexus within the institution-based view: A nonlinear specification with varying coefficients. Int. Bus. Rev. 2019, 28, 415-427. [CrossRef]

51. Rehman, F.; Ding, Y.; Noman, A.A.; Khan, M.A. China's outward foreign direct investment and exports diversification: An asymmetric analysis. J. Chin. Econ. Foreign Trade Stud. 2020, 13, 45-69. [CrossRef]

52. Rehman, F.; Ding, Y. The nexus between outward foreign direct investment and export sophisti-cation: New evidence from China. Appl. Econ. Lett. 2019, 27, 357-365. [CrossRef]

53. Zivot, E.; Andrews, D.W.K. Further Evidence on the Great Crash, the Oil-Price Shock, and the Unit-Root Hypothesis. J. Bus. Econ. Stat. 2002, 20, 25-44. [CrossRef]

54. Narayan, P.K. The saving and investment nexus for China: Evidence from cointegration tests. Appl. Econ. 2005, 37, 1979-1990. [CrossRef]

55. Gupta, S.; Kumar, N. Time varying dynamics of globalization effect in India. Port. Econ. J. 2020, 1-17. [CrossRef]

56. Bahmani-Oskooee, M.; Mohammadian, A. Who benefits from euro depreciation in the euro zone? Empirica 2019, 46, 577-595. [CrossRef]

57. Bahmani-Oskooee, M.; Ratha, A. The J-Curve: A literature review. Appl. Econ. 2004, 36, 1377-1398. [CrossRef]

58. Lucarelli, S.; Andrini, F.U.; Bianchi, A. Euro depreciation and trade asymmetries between Germany and Italy versus the US: Industry-level estimates. Appl. Econ. 2018, 50, 15-34. [CrossRef]

59. Rehman, F.U.; Khan, M.A.; Pervaiz, K.; Liaqat, I. The causal, linear and nonlinear nexus between sectoral FDI and infrastructure in Pakistan: Using a new global infrastructure index. Res. Int. Bus. Financ. 2020, 52, 101129. [CrossRef] 